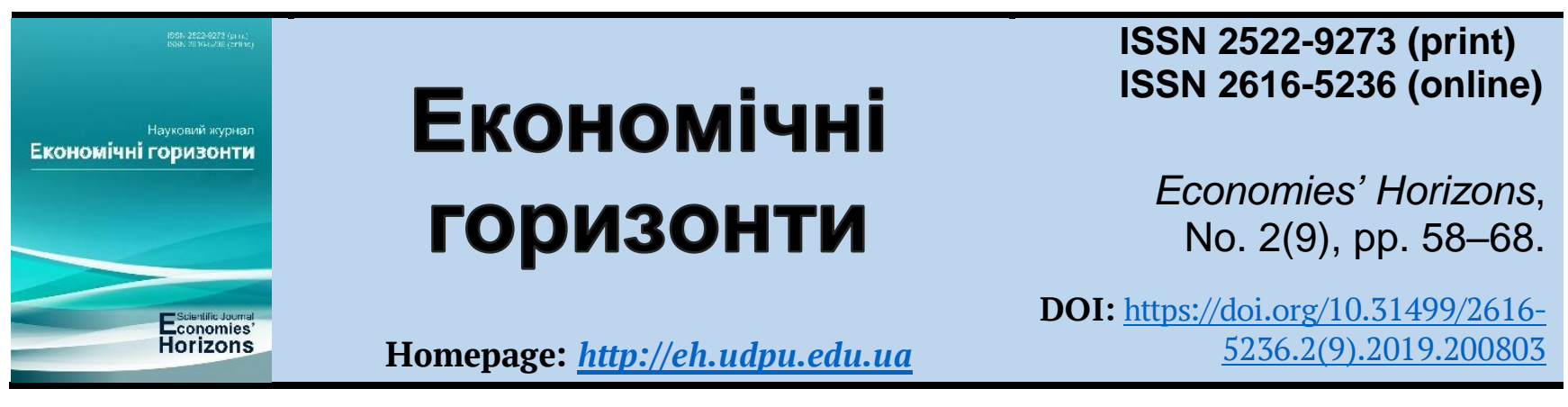

UDC 338.448.2(477.63)

\title{
Evaluation of reserve economic development of production potential of the enterprise of the hotel and restaurant industry in Dnipropetrovsk region
}

\author{
Olena I. Judina ${ }^{1}$, Cand. Ec. Sc.
}

Received: 28 April 2019

Accepted: 30 May 2019
Judina, O. I. (2019), "Evaluation of reserve economic development of production potential of the enterprise of the hotel and restaurant industry in Dnipropetrovsk region", Economies' Horizons, no. 2(9), pp. 58-68, doi: https://doi.org/10.31499/26165236.2(9).2019.200803.

Abstract. The purpose of the research. The purpose of this work is economic and mathematical modeling of features of interaction of production resources at the hotel and restaurant business and assessment of reserve development of their potential on the basis of coefficients that reveal the possibility of increasing the economic efficiency of the resource consumption process. Methodology. The methodology of the research is based on fundamental principles of enterprise economics, econometrics, mathematical statistics, as well as publications of domestic and foreign scientists on the problems of economic development of enterprises. To analyze and evaluate the reserve economic development of the productive potential of the hotel and restaurant business based on the coefficients and indicators of economic development of factors of production used general scientific and special research methods, including grouping, statistical, stochastic, correlation-regression analysis, methods of economic and mathematical modeling, mathematical statistics. Tabular technique was used to clearly present the results of the study. Results. In the work by means of economic and mathematical modeling, models of multiple regression of production activity, variable costs and production efficiency are constructed. On the basis of the mathematical equations obtained, the regularities of the mutual influence of factors of production are explained, the estimated coefficients and indicators of the reserve economic development of the production potential of the hotel and restaurant enterprise are determined. With the help of the calculated estimation parameters, the power of indirect and direct action of a particular factor on the efficiency of the business entity's performance, the contribution of the factor to the cumulative influence of all factors, the possibility of revenue growth due to the development of resource potentials have been established. By interpreting certain estimated coefficients, a mathematical formula is proposed to calculate the indicators of a reserve economic development of an enterprise, which allow establishing reserves of growth of a productive indicator due to the development of a certain resource, taking into account the share of its contribution to the integrated effect of factors. On the basis of the models of multiple regression of production activity of the enterprises of the hotel and restaurant industry the regularity of mutual influence of the studied economic indicators is established, the coefficients and indicators of economic growth and reserve development are calculated, as well as their quantitative parameters by which the differentiated and integrated influence of the elements of the investigated elements is determined, an assessment of the reserve economic development of production potential. Practical meaning. The proposed methods of analysis and evaluation of indicators were used in the formation of the organizational structure of the

${ }^{1}$ Higher Education Private Institution "Dnipro Humanitarian University"; Head of the Department of Hotel and Restaurant Business; ORCID ID: https://orcid.org/0000-0003-3699-5321; e-mail: el.judina@gmail.com. 
system of management of economic growth and development of the enterprise. The prospects for further research are to create a model for managing the sustainable economic development of hotel and restaurant businesses.

Keywords: economic and mathematical modeling, multiple regression model, coefficients, indicators, estimation parameters, analysis. enterprise, reserves of economic development.

JEL Classification: O12, O47, Z32.

Number of references: 10; number of tables: 4; number of figures: 0; number of formulas: 7.

\section{Оцінка резервного економічного розвитку виробничого потенціалу підприємства готельно-ресторанного господарства Дніпропетровської області}

Стаття надійшла: 28.04.2019 Стаття прийнята: 30.05.2019

\author{
Олена Іванівна Юдіна ${ }^{1}$, к. е. н.
}

Judina O. I. Evaluation of reserve economic development of production potential of the enterprise of the hotel and restaurant industry in Dnipropetrovsk region. Економічні горизонти. 2019. № 2(9). C. 58-68. DOI: 10.31499/26165236.2(9).2019.200803.

Анотація. Метою статті є економіко-математичне моделювання особливостей взаємодії ресурсів виробництва на підприємстві готельно-ресторанного господарства та оцінка резервного розвитку їх потенціалу на основі коефіцієнтів, що виявляють можливості зростання економічної ефективності процесу ресурсоспоживання. Методологія дослідження базується на фундаментальних положеннях економіки підприємства, економетрики, математичної статистики, а також публікаціях вітчизняних і зарубіжних учених з проблематики економічного розвитку підприємств. Для проведення аналізу та оцінки резервного економічного розвитку виробничого потенціалу підприємства готельно-ресторанного господарства на основі коефіцієнтів та індикаторів економічного розвитку факторів виробництва використано загальнонаукові та спеціальні методи дослідження, зокрема групування, статистичного, стохастичного, кореляційно-регресійного аналізу, методи економіко-математичного моделювання, математичної статистики. Табличний прийом застосовувався для наочного подання результатів дослідження. Результати. У роботі шляхом економіко-математичного моделювання побудовано моделі множинної регресії виробничої діяльності, змінних витрат та ефективності виробництва. На основі отриманих математичних рівнянь пояснено закономірності взаємовпливу факторів виробництва, визначено оцінні коефіцієнти та індикатори резервного економічного розвитку виробничого потенціалу підприємства готельно-ресторанного господарства. За допомогою розрахованих оцінних параметрів встановлено силу опосередкованої та прямої дії конкретного фактора на ефективність результатів роботи суб'єкта господарювання, частки внеску фактора в сумарний вплив всіх факторів, можливості зростання доходу за рахунок розвитку ресурсних потенціалів. Шляхом інтерпретації визначених оцінних коефіцієнтів запропоновано математичну формулу для розрахунку індикаторів резервного економічного розвитку підприємства, які дозволяють встановити резерви зростання результативного показника за рахунок розвитку певного ресурсу з урахуванням частки його внеску в інтегровану дію факторів. Доведено, що найбільший прямий і опосередкований вплив на зростання ефективності результатів діяльності підприємств готельно-ресторанної сфери надають

\footnotetext{
${ }^{1}$ Вищий навчальний приватний заклад «Дніпровський гуманітарний університет»; завідувач кафедри готельно-ресторанного бізнесу; ідентифікатор ORCID: https://orcid.org/0000-0003-3699-5321; e-mail: el.judina@gmail.com.
} 
фактори витрат праці й матеріальних витрат, які тісно зв'язані між собою, оскільки процес обслуговування, що здійснюється персоналом, безпосередньо зв'язаний з витратами матеріальних ресурсів, і його якість в значній мірі залежить від рівня розвитку матеріально-технічної бази підприємства. Також встановлено, що у виробничої діяльності найбільші резерви розвитку мають ресурси праці. Практичне значення. Запропоновані методи аналізу і оцінні показники використано у формуванні організаційної структури системи управління економічним зростанням та розвитком підприємства. Перспективи подальших досліджень полягають у створенні моделі управління сталим економічним розвитком підприємств готельно-ресторанного господарства.

Ключові слова: економіко-математичне моделювання, модель множинної регресії, коефіцієнти, індикатори, оцінні параметри, аналіз. підприємство, резерви економічного розвитку.

Кількість джерел: 10; кількість таблиць: 4; кількість рисунків: 0; кількість формул: 7.

\section{Introduction.}

The complexity and variability of the enterprise functioning have created the conditions for various models of their activity organization, the adequacy of which is estimated by the specific situation in which the business entity or its units operates, depending on the state of the external and internal environment. It is impossible to study the enterprise without taking into account the time periods, dynamics and statics, as well as mechanisms that ensure the performance of functions and efficiency of activity. In this case, the economic unit is considered as a set of processes (means) and tools, as a subject of collective activity, an object that has certain properties and characteristics, which interacts with other objects and processes of the environment. In addition, an enterprise as a whole consists of local aggregates of interconnected elements aimed at performing the diverse private functions necessary for the functioning of a single economic system. The following characteristics are the important features of its integrity:

- differentiation of processes (components, elements) and specialization for performing various functions and activities;

- connection, organization, coordination, integration.

Also, the enterprise is a system integrator, since its functioning as an entity combines in time and space a set of various economic processes aimed at producing products (services) and profit by extracting subsystem effects and synergy results, where each element performs certain tasks to achieve the goals of the enterprise, influences its efficiency and sustainable economic development.

Target setting. Therefore, establishment and assessment of reserves for economic growth and development of the hotel and restaurant industry necessitates the study of their functioning in the present time, identification patterns of interaction of processes and elements of the entity as an economic system.

\section{Literature review.}

The studies of many scientists, such as R. Akoff (1984), I. Ansoff (1989), B. Raizberg (1995), G. Merzlikina (1997), S. Borodich (2001), V. Medvedev (2001), S. Radchenko (2005), V. Vasilenko (2005), B. Andrushkiv, Yu. Vovk and E. Vovk (2012), N. Fedotova (2017) and others are devoted to the evaluation of reserve economic development of production potential and ensuring sustainable economic growth of enterprises.

In the research of $B$. Andrushkiv, Yu. Vovk and E. Vovk (2012), attention is paid to the indices characterizing the resource reserves of enterprises and the directions of their innovative development. In the works of I. Ansoff (1989) and R. Akoff (1984) the quantitative parameters of indices that constitute production potential but do not characterize the category of "economic development" are determined. V. Vasilenko (2005) defines the individual components, structural units of the enterprise and processes, effective management of which ensures the economic development through the use of an organizational system of management reserves. G. Merzlikina (1997) considers sustainable 
economic development of an enterprise as a state of its balance, and considers it expedient to manage the adaptability of the economic entity to changes, first of all, of the external environment. In the work of N. Fedotova (2017) a higher form of economic development that provides sustainability is considered to maintain the enterprise balance under the influence of external and internal factors, which proposes to create a system for managing the economic and social stability of the enterprise. According to B. Raizberg (1995), the economic development of an enterprise is based on the strengthening of its financial position, which makes it possible to fulfill all the obligations due to sufficient income. V. Medvedev (2001) characterizes the sustainable economic development of the enterprise as the process of creating a balanced state of economic resources, which provides stable profitability taking into account the most important external and internal factors.

However, there is no approach to assessing the reserve economic development of the production potential of the hotel and restaurant industry by establishing the regularities of interaction of production factors, determining the reserves of economic growth and sustainable development of the economic entity on the basis of economic and mathematical modeling of production activity and determining its point ratings.

\section{Methods.}

During the analysis and evaluation of the reserve economic development of the production potential of the hotel and restaurant industry enterprise based on the factors and indices of economic development of production factors, the general scientific and special research methods were used, including grouping method, statistical method, stochastic method, method of correlation-regression analysis, method of economical and mathematical modeling, mathematical statistics method. Tabular technique was used to clearly present the results of the study. The information base of the paper is the materials of periodicals, scientific works, Internet-resources, official statistical materials.

\section{Research objectives.}

Economic and mathematical modeling of features of interaction of production resources at the enterprise of the hotel and restaurant industry and evaluation of the reserve development of their potential on the basis of coefficients which reveal the possibilities of increase of economic efficiency of the resource consumption process.

\section{Results and discussions.}

Evaluation of the reserve economic development of production potential, which is carried out by means of coefficient and correlation-regression analysis by economic-mathematical modeling, allows to determine the properties of processes, to adequately assess the regularity of interaction of constituent elements, as well as their differentiated influence to the general result.

In order to establish the regularities of the resource and production potential development and its impact on the paper results and economic growth of the enterprises of hotel and restaurant industry, models of correlation interdependence of the studied parameters, which are constituent elements of a certain block of potentials, namely the production activity, variables of production efficiency costs, have been developed. The general view of the developed multiple regression models is characterized by the following mathematical equation:

$$
G_{i}=b_{0}+b_{1} K_{1}+b_{2} K_{2}+\ldots+b_{i} K_{i}+e_{i}
$$

where $G_{i}$ is a dependent (predicated) variable or the efficiency (profitability) index of an enterprise;

$K_{i}=K\left(K_{1}, K_{2}, \ldots, K_{n}\right)$ - vector of independent (predicated) variables or level of resources consumption in the production process;

$b_{i}$ - vector of parameters to be determined;

$e_{i}$ - accidental error (deviation); 
$b_{0}$ is an absolute term of this mathematical equation that determines the value of $G_{i}$, with all the predicated variables $K_{i}$, equal to 0 .

In course of the study of quantitative interaction of cost indices and the degree of influence of production factors on the profitability level of the enterprise of the index of the material expenses level $\left(K_{M E}\right)$, index of the labor expenses level $\left(K_{L E}\right)$ and index of the main fixed assets expenses level $\left(K_{F A E}\right)$ per one hryvnia of operating costs were used and a model of multiple regression of production activity (2) and variable costs (3) was developed:

$$
\hat{G}_{P E}=0.9084-0.3358 * \bar{K}_{M E}+1.155287 * \bar{K}_{L E}-1.28638 * \bar{K}_{F A E} \text {, }
$$

where $\hat{G}_{P E}$ is the theoretical (estimated) value of the profitability level of the enterprise;

$\bar{K}_{M E}$ - average value of material expenses level;

$\bar{K}_{L E}$ - the average value of labor expenses level;

$\bar{K}_{F A E}$ - average value of the main fixed assets expenses level;

$$
\hat{G}_{P E V}=0.66174-0.751 * \bar{K}_{M E}+1.73381 * \bar{K}_{L E},
$$

where $\hat{G}_{P E V}$ is the theoretical (estimated) value of the profitability level of the enterprise under the influence of variable costs of production activity of the enterprise.

These economic and mathematical models of the dependence of the profitability level of the economic entity on material expenses, fixed assets expenses and labor expenses are the basis for the calculation of the relevant coefficients for the analysis and evaluation of reserves of development of resource potentials, strength and degree of influence of the studied factors (resources consumption) to increase the efficiency of operation and development of the production potential of the hotel and restaurant industry.

Thus, reserves for the economic indices development of production resource potential of the enterprises of the hotel and restaurant industry are determined using the appropriate multiple regression model and $\beta_{K i}$ coefficients, which characterize the direct influence and degree of variation of the root mean square deviation values of the factor parameters regarding the standard deviations of the effective sign taking into account the coefficient value under the economic and mathematical model factors.

On the basis of the developed models of multiple correlation dependence, it becomes possible to establish the force of indirect action of a certain factor $K_{i}$ on the result $G$ (profitability level) through the other indices of expense, by calculating the evaluation parameter $d_{K i}$, which is equal to the product of the coefficient $\beta_{K i}$ and the private correlation coefficient $r_{G K i}\left(d_{K i}=\beta_{K i}{ }^{*} r_{G K i}\right)$ The sum of the given products $\left(\sum \beta_{K i}{ }^{*} r_{G K i}\right)$ of all factors included in the economic and mathematical model determines the value of its determination coefficient $R^{2}$, and describes the variation of the resource cost indices, which characterize the variation of the effective parameter in the equation. The use of the above coefficients in a further study allows to calculate the share of the contribution of the i-th factor to the sum of the influence of all factors (the coefficient $h_{K i}$ ) by dividing the indirect influence value of this factor $\left(d_{K i}\right)$ by the determination coefficient $\left(R^{2}\right)$.

Besides, the analysis of changes in the effective index in accordance with the change in the value of a single factor by $1 \%$ under a fixed position of other factor parameters, is carried out by determining the individual coefficients of elasticity or economic growth indices:

$$
E_{\mathrm{C} K i}=a_{i} \frac{\overline{K_{l}}}{\overline{G_{l}}}
$$

where $E_{C K i}$ is the economic growth index of the $i$-th factor;

$a_{i}$ is the regression coefficient at the $i$-th factor; 
$K_{i}$ is the average value of the $i$-th factor;

$\left(\bar{G}_{l}\right)$ is the average value of the effective index.

In the course of the research, by interpreting the presented evaluation parameters of the developed models of multiple correlation dependence, the mathematical formula for calculating the reserve economic development indices, which allow to establish reserves for the effective index growth due to the development of a certain resource, taking into account the share of its contribution to the integrated effect of the factors:

$$
R_{C K i}=h_{K i} * E_{C K i},
$$

$R_{C K i}$ is the reserve economic development index of the $i$-th factor;

$h_{K i}$ is the coefficient of the specific gravity (degree) of contribution of the $i$-th factor to the total amount of influence of the factors;

$E_{C K i}$ is an economic growth index of the $i$-th factor.

Quantitative evaluation parameters obtained by calculating the proposed coefficients based on multiple regression models of production activity (2) and variable costs (3) are given in the Tables 1 and 2.

\section{Table 1. Evaluation of the reserve economic development of the production potential of the hotel and restaurant enterprise in Dnipropetrovsk region on the basis of the production model}

\begin{tabular}{|c|c|c|c|c|c|c|c|c|}
\hline \multirow{2}{*}{$\begin{array}{l}\text { Economic indices of } \\
\text { production model }\end{array}$} & \multicolumn{8}{|c|}{$\begin{array}{c}\text { Indices of the assessment of the impact of factors on the activity results } \\
\text { and their reserve development }\end{array}$} \\
\hline & $\overline{K_{l}}$ & $\overline{\sigma_{K_{l}}}$ & $\boldsymbol{\beta}_{K_{i}}$ & $r_{G_{i} K_{i}}$ & $d_{K_{i}}$ & $\boldsymbol{h}_{K_{i}}$ & $E_{C K_{i}}$ & $\boldsymbol{R}_{C K_{i}}$ \\
\hline $\begin{array}{l}\text { 1. Material } \\
\text { expenses level }\end{array}$ & 0.35031 & 0.05811 & -0.2660 & -0.915 & 0.2422 & 0.35076 & -0.110 & -0.0387 \\
\hline $\begin{array}{l}\text { 2. Labor expenses } \\
\text { level }\end{array}$ & 0.24862 & 0.03331 & 0.7206 & 0.819 & 0.590 & 0.85451 & 0.370 & 0.3164 \\
\hline $\begin{array}{l}\text { 3. Main fixed } \\
\text { assets expenses level }\end{array}$ & 0.09261 & 0.01272 & -0.2228 & 0.13 & -0.290 & 0.04194 & -0.112 & -0.0047 \\
\hline $\begin{array}{l}\text { 4. Enterprise } \\
\text { income level }\end{array}$ & \multicolumn{3}{|c|}{$\overline{\mathbf{G}_{\mathbf{1}}}=1.06649 ; \overline{\sigma_{\mathbf{G}_{\mathbf{1}}}}=0.07342$} & - & - & - & - & - \\
\hline
\end{tabular}

The standardized evaluation parameters in the production model, presented in Table 1 , reflect the close connection, strength, extent and reserves of the influence of factors on the enterprise income level. The standardized coefficient $\beta_{K i}$ indicates that, in the aggregate of factors, the labor cost factor has the greatest direct effect on the resultant index, taking into account the level of their variation. Besides, this factor characterizes the labor expenses index as a factor in the development of which the largest reserves of the enterprise income increase are set. The $\beta$-coefficient value indicates that under the change of the labor expenses factor value by 0.033 , the level of in- come will increase by 0.721 of its standard deviation value, and by reducing the material expenses level by 0.058 and the fixed assets expenses by 0.013 , the profitability index will increase by 0.266 and 0.223 of its standard deviation respectively.

The study based on the private correlation coefficient $r_{G i K i}$ allowed us to conclude that the strongest direct individual and indirect influence through other factors on the effective index, has a material expenses factor, its value is 0.911 , the next are the labor expenses (0.819) and the fixed assets expenses (0.13). Such evaluation of the parameters is explained by the fact that the two previous factors relate 
to the variable production costs and are directly dependent on the volume of goods and services produced, and, as is well known, the hotel and restaurant business is a labor-dominant type of economic activity. Therefore, the work of the staff of the hotel and restaurant complexes in providing the process of service, directly related to the cost of material resources, and its quality largely depends on the level of development of material and technical base of the enterprise.

Based on the analysis of the $d_{K i}$ coefficient it follows that the highest degree of indirect impact on the result of activity also has a labor intensity index (0.59), followed by the level of indirect impact are the capital consumption indices (0.29) and material consumption indices $(0.242)$ of production.

Based on the study of the parameters of the evaluation characteristic $h_{K i}$, it is found that the largest share of the income level increase can be provided by the development of labor factor (0.855), the second factor for the increase in the level of profitability is the factor of material expenses, its share is 0.351 .

The Private Economic Growth Indicator $E_{C K i}$ indicates that a $1 \%$ increase in the labor expenses level, a $1 \%$ decrease in material and production costs will lead to an increase of $0.37 \%, 0.11 \%$ and $0.112 \%$, respectively. The calculated data of the proposed reserve development indicator of $R_{C K i}$ factors also confirms that to a greater extent the increase of the efficiency of the enterprise operation is influenced by the change of the labor costs index, its increase by $1 \%$ will influence the growth of income by $0.32 \%$, and at decrease of capital consumption (0.29) and material consumption indices (goods services) by $1 \%$, there is an increase in the level of income by $0.04 \%$ and $0.005 \%$, respectively.

In the course of the analysis of the evaluation characteristics of economic growth on the basis of the reserve development of factors of variable costs of the enterprise of the hotel and restaurant industry of Dnipropetrovsk region, it is confirmed that a higher level of the aggregate direct, as well as the differentiated direct and indirect influence on the enterprise income, provides a labor cost factor with the corresponding values of coefficients:

$$
\begin{aligned}
& \beta_{\mathrm{K}_{L E}}=0.787 ; \\
& r_{G d \mathrm{~K}_{L E}}=0.819 ; \\
& d_{\mathrm{K}_{L E}}=0.644 .
\end{aligned}
$$

Also, the coefficient $h_{\mathrm{K}_{L E}}$ which characterizes the share of growth in the level of income due to the development of labor expenses factor, has the largest value, which is 0.957, and the economic growth indices $E_{C \kappa_{L E}}$ and reserve development factors $R_{C \kappa_{L E}}$ show that the increase of costs for improving labor resources by $1 \%$, will contribute to income growth of $0.4 \%$ and $0.32 \%$, respectively. Using the differentiated factor evaluation, it was found that the material consumption index also has a significant impact on the activity, but takes the second place with the following qualitative characteristics:

$$
\begin{aligned}
& \beta_{\mathrm{K}_{M E}}=(-0.595) ; \\
& r_{G d \mathrm{~K}_{M E}}=0.478 ; \\
& d_{\mathrm{K}_{M E}}=0.29 ; \\
& h_{\mathrm{K}_{M E}}=0.43 ; \\
& E_{C \mathrm{~K}_{M E}}=(-0.247) ; \\
& R_{C \mathrm{~K}_{M E}}=(-0.039) \text { (see Table 2). }
\end{aligned}
$$

In the same manner, the analysis and assessment of the reserve economic development of production potential using the multiple regression model of production efficiency was conducted (6):

$$
\hat{G}_{P E C_{1}}=0.5013+0.9775 * \bar{K}_{P M E}-0.01547 * \bar{K}_{P L E}+0.02786 * \bar{K}_{P F A E},
$$

where $\hat{G}_{P E C 1}$ is the theoretical (expected) value of the profitability level of the enterprise activity under the influence of indices of the cost of production activity of the enterprise; 
Judina O. I. Evaluation of reserve economic development of production potential of the enterprise of the hotel and restaurant industry in Dnipropetrovsk region

$\bar{K}_{P M E}$ is the average value of the profitability level of material costs calculated using $1 \mathrm{UAH}$ of the enterprise income;

$\bar{K}_{P L E}$ is the average value of the profitability level of labor expenses calculated using 1 UAH of the enterprise income;

$\bar{K}_{P F A E}$ is the average value of the profitability level of main fixed assets expenses calculated using $1 \mathrm{UAH}$ of the enterprise income.

Table 2. Evaluation of economic growth on the basis of reserve development of variable costs factors of the hotel and restaurant enterprise in Dnipropetrovsk region

\begin{tabular}{|c|c|c|c|c|c|c|c|c|}
\hline \multirow{2}{*}{$\begin{array}{l}\text { Economic indices } \\
\text { of variable costs } \\
\text { model }\end{array}$} & \multicolumn{8}{|c|}{$\begin{array}{c}\text { Indices of the assessment of the impact of factors on the activity results } \\
\text { and their reserve development }\end{array}$} \\
\hline & $\overline{K_{l}}$ & $\overline{\sigma_{K_{l}}}$ & $\boldsymbol{\beta}_{K_{i}}$ & $\boldsymbol{r}_{G_{i} K_{i}}$ & $d_{K_{i}}$ & $\boldsymbol{h}_{\boldsymbol{K}_{i}}$ & $E_{C K_{i}}$ & $\boldsymbol{R}_{C K_{i}}$ \\
\hline $\begin{array}{l}\text { 1. Material } \\
\text { expenses level }\end{array}$ & 0.35031 & 0.05811 & -0.5947 & 0.48668 & 0.2895 & 0.431 & -0.2467 & -0.10611 \\
\hline $\begin{array}{l}\text { 2. Labor expenses } \\
\text { level }\end{array}$ & 0.24862 & 0.03331 & 0.7866 & 0.81887 & 0.6441 & 0.957 & 0.4042 & 0.3941 \\
\hline $\begin{array}{l}\text { 3. Level of } \\
\text { enterprise income }\end{array}$ & \multicolumn{3}{|c|}{$\overline{\mathbf{G}_{\mathbf{1}}}=1.06649 ; \overline{\sigma_{\mathrm{G}_{\mathbf{1}}}}=0.07342$} & - & - & - & - & - \\
\hline
\end{tabular}

The evaluation parameters calculated on correlation dependences are given in Table 3 . the basis of the presented model of multiple

Table 3. Evaluation of the reserve economic development of the production efficiency indices of the hotel and restaurant enterprise in Dnipropetrovsk region on the basis of the production model

\begin{tabular}{|c|c|c|c|c|c|c|c|c|}
\hline \multirow{2}{*}{$\begin{array}{l}\text { Economic indices of pro- } \\
\text { duction efficiency model }\end{array}$} & \multicolumn{8}{|c|}{$\begin{array}{c}\text { Indices of the assessment of the impact of factors on the activity re- } \\
\text { sults and their reserve development }\end{array}$} \\
\hline & $\overline{K_{l}}$ & $\overline{\sigma_{K_{l}}}$ & $\boldsymbol{\beta}_{K_{i}}$ & $\boldsymbol{r}_{G_{i} K_{i}}$ & $d_{K_{i}}$ & $\boldsymbol{h}_{K_{i}}$ & $E_{C K_{i}}$ & $\boldsymbol{R}_{C K_{i}}$ \\
\hline 1. Material expenses level & 3.1362 & 0.64744 & 8.6199 & 0.772 & 6.653 & 7.381 & 2.875 & 21.215 \\
\hline 2. Labor expenses level & 4.3377 & 0.4048 & -0.0853 & -0.462 & 0.039 & 0.0437 & -0.063 & 0.003 \\
\hline $\begin{array}{l}\text { 3. Level of the fixed assets } \\
\text { cost effectiveness }\end{array}$ & 11.694 & 1.47835 & 0.561 & 0.351 & 0.197 & 0.2184 & 0.306 & 0.067 \\
\hline $\begin{array}{l}\text { 4. Level of enterprise in- } \\
\text { come }\end{array}$ & \multicolumn{3}{|c|}{$\overline{\mathbf{G}_{\mathbf{1}}}=1.06649 ; \overline{\sigma_{\mathbf{G}_{\mathbf{1}}}}=0.07342$} & - & - & - & - & - \\
\hline
\end{tabular}

The research based on the evaluation characteristics of the reserve development of production efficiency indices at the enterprise of the hotel and restaurant industry in Dnipropetrovsk region have found that the largest development reserves in ensuring the increase of the enterprise efficiency, are set in the factor of material costs profitability, as evidenced by the coefficient $\beta_{K_{P M E}}$, with the value of 8.62, the second, but much smaller under the $\beta$-coefficient value, is the fixed assets cost effectiveness index $\beta_{K_{P F A E}}=0.561$ ). In addition, the calculated coefficients of the contribution rate of the factor $h_{K i}$, made it possible to establish that the development of the factor of material cost efficiency, the coefficient $h_{K_{P M E}}$ of which is 7.381 , can make a significant contribution to the increase in the income of the hotel and restaurant business.

According to the other parameters of evaluation of the production efficiency model, shown in Table 3, the material expenses index also has the highest characteristics. Direct individual and indirect influence of this factor on 
production efficiency is: 0.772 and 6.653 , that is, $r_{G d \mathrm{~K}_{L P}}=0.772 ; d_{\mathrm{K}_{L P}}=6.653$. The factor of the labor expenses coefficient $\left(r_{G d K_{L P}}=0.462\right)$ takes the second place in terms of direct differential impact which, unlike its influence in general, has a positive value.

The primary importance of sustainable growth in the above-mentioned factor is confirmed by the economic growth indices $\left(E_{C K_{L P}}\right)$ and reserve development indices $\left(R_{C K_{L P}}\right)$ which show that the growth of the enterprise's income level is more dependent on the change of material costs profitability, so an increase of this economic index by $1 \%$ will cause an increase in the level of income by $2.88 \%$, and taking into account the degree of its contribution to the total influence of factors - by $21.22 \%$. Increasing the efficiency of the fixed assets use by $1 \%$ will allow to increase the level of income by $0.31 \%$ and $0.01 \%$ (taking into account the share of index contribution in the integrated effect of factors).

Also, the assessment of the dependence of the interrelation of aggregate performance factors, taking into account the labor productivity index using the following multiple regression model:

$$
\hat{G}_{P E C_{2}}=0.5095+0.07026 * \bar{K}_{P M E}+0.06458 * \bar{K}_{P L E}+0.0296 * \bar{K}_{P F A E}-0.00326 * \bar{K}_{L P},
$$

where $\hat{G}_{P E C 2}$ is the theoretical (expected) value of the profitability level of the enterprise under the influence of the effectiveness of production activity expenses of the enterprise taking into account the factor of productivity;

$\bar{K}_{\Pi I I}$ is the level of labor productivity.

Such model describes the nature of interrelation and the quantitative ratio of effective indices and confirms the main trend of development of the hotel and restaurant industry enterprises in Dnipropetrovsk region. This model emphasizes that increasing labor productivity and increasing labor resource efficiency by $1 \%$ contributes to an increase in income by $0.533 \%$ and $0.291 \%$, respectively, and an increase in the efficiency of material resources and fixed assets by $1 \%$, as well as contributes to an increase in income by $0.506 \%$ and $0.487 \%$, respectively (see Table 4 ).

\section{Table 4. Evaluation of the reserve development of the production efficiency indices taking into account the labor productivity factor of the hotel and restaurant enterprise in}

Dnipropetrovsk region

\begin{tabular}{|c|c|c|c|c|c|c|c|c|}
\hline \multirow{2}{*}{$\begin{array}{c}\text { Economic indices of } \\
\text { production efficiency } \\
\text { model }\end{array}$} & \multicolumn{8}{|c|}{$\begin{array}{l}\text { Indices of the assessment of the impact of factors on the activity re- } \\
\text { sults and their reserve development }\end{array}$} \\
\hline & $\overline{K_{1}}$ & $\overline{\sigma_{K}}$ & $\boldsymbol{\beta}_{K_{i}}$ & $\boldsymbol{r}_{G_{i} K}$ & $\boldsymbol{d}_{K_{i}}$ & $\boldsymbol{h}_{K}$ & $\boldsymbol{E}_{C K_{i}}$ & $\boldsymbol{R}_{C K .}$ \\
\hline 1. Material expenses level & 3.136 & 26474 & 1505 & & & 0.4067 & 0.207 & $00^{\prime}$ \\
\hline 2. Labor expe & 4.33 & & & -0.462 & 0.1 & & 0.263 & 0.037 \\
\hline $\begin{array}{l}\text { 3. Level of th } \\
\text { assets cost ef }\end{array}$ & 1 & 1. & 0.4 & 0 . & 0 & 0 . & 0.325 & 0.058 \\
\hline $\begin{array}{l}\text { 4. Level of labor } \\
\text { productivity }\end{array}$ & 20.4233 & 1.9103 & 0.53 & 0.67 & 0.3573 & 0.3722 & 0.272 & 0.101 \\
\hline $\begin{array}{l}\text { 5. Level of enterprise } \\
\text { income }\end{array}$ & \multicolumn{3}{|c|}{$\overline{\mathbf{G}_{\mathbf{1}}}=1.06649 ; \overline{\sigma_{\mathbf{G}_{1}}}=0.07342$} & - & - & - & - & - \\
\hline
\end{tabular}

In addition, it was found that the material expenses indices $\quad\left(r_{G d K_{M E}}=0.772\right.$; $\left.d_{\mathrm{K}_{M E}}=0.391\right)$ and labor productivity indices $\left(r_{G d K_{L P}}=0.67 ; d_{\mathrm{K}_{L P}}=0.357\right)$ also have the greatest direct and indirect effect on the growth of the efficiency of business results. They also have higher values of the share of contribution to the cumulative influence of factors 
$\left(h_{\mathrm{K}_{M E}}=0.407 ; h_{\mathrm{K}_{L P}}=0.372\right)$ and reserve development indices $\quad\left(R_{C \kappa_{M E}}=0.084\right.$; $\left.R_{C \kappa_{L P}}=0.101\right)$. And the static economic growth indicator $E_{\mathrm{CK}_{F A E}}$, shows the highest level of increase of the enterprise income due to the main fixed assets improvement, that is, with the increase of the efficiency index of the fixed assets expenses by $1 \%$, the volume of income will increase by $0.325 \%$.

\section{Conclusions.}

On the basis of the developed multiple regression models of production activity of the enterprises of the hotel and restaurant industry the regularity of mutual influence of the studied economic indices are established, the coefficients and indices of economic growth and reserve development are calculated, as well as their quantitative parameters with the help of which different influence of the elements of the studied processes on the general result is defined and the assessment of reserve economic development production potential is carried out.

The obtained qualitative characteristics of the studied processes with the help of the offered economic-mathematical models, coefficients and indicators indicate that a very important factor in the process of production and service in the hotel and restaurant business, which greatly influences the results of business entities functioning, is the staff (human resources). And the increase in labor productivity is directly related to the material resources consumption, their quality and efficiency of use. The high quality and efficiency of work in the field of hotel and restaurant industry is ensured by the availability of a developed material and technical base, modern tools and objects of work, which is confirmed by the created regression models that describe the regularity of the relationship of these processes. That is, with the help of the developed economic and mathematical models, it becomes possible to mathematically describe the patterns of interdependence of factors and results of the studied processes, to establish their quantitative interrelation, as well as possible individual and aggregate reserves of development, ensuring sustainable economic growth of the enterprise.

Thus, by analyzing and evaluating the parameters of the presented multiple regression models, it is found that they are generally characterized by high qualitative assessment, are adequate, however, the private correlation coefficients of such factor features as the level of main production funds expenses and other operating costs have not high enough values. This can be explained by the fact that there is no close linear relationship between these factors and the effective index, and there are other complex relationships with other factors. Therefore, in order to establish an individual form of link between the studied economic indices, a more accurate and detailed description of the patterns of interaction and the degree of mutual influence of the studied factor parameters, it is advisable in the further study to develop the pair correlation models, which will allow to identify and mathematically describe the dynamics production and to set modern trends of their economic development.

\section{References}

Andrushkiv, B. M., Vovk, Yu. Ya. and Vovk, E. P. (2012), Resursonomika: teoretichni ta pricladni aspekti [Resource economics: theoretical and applied aspects], Terno-graf, Ternopil, Ukraine, 456 p.

Ansoff, I. (1989), Strategicheskoe upravlenie [Strategic management], Ekonomika, Moskow, Russia, 519 p.

Akoff, R. (1984), Planirovanie budushchego korporatcii [Creating the corporate future], Progress, Moskow, Russia, $328 \mathrm{p}$.

Borodich, S. A. (2001), Ekonometrika [Econometrics], Novoe znanie, Minsk, Belarus, 408 p.

Fedotova, N. V. (2017), "Essence and factors of enterprise finansial stability", Transport Business in Russia, no. 3, pp. 29-30, available at: https://cyberleninka.ru/article/n/suschnost-i-faktory-finansovoyustoychivosti-predpriyatiya/viewer (Accessed 10 April 2019). 
Medvedev, V.A. (2001), Ustoichivoe razvitie obshchestva: modeli, strategiia [Sustainable development of society: models, strategy], Akademiia, Moscow, Russian, 267 p.

Merzlikina, G. S. (1997), Ekonomicheskaia sostoiatelnost proizvodstvennykh system [Economic viability of production systems], Vysshaia shkola, Moscow, Russian, 160 p.

Radchenko, S. G. (2005), Ustoichivye metody otcenivaniia statisticheskikh modelei [Stands for estimating statistical models], PP “Sansparel”, Kiev, Ukraine, 504 p.

Raizberg, B. A. (1995), Rynochnaia ekonomika [Market economy], Delovaia zhizn, Moscow, Russian, 432 p.

Vasilenko, A. V. (2005), Menedzhment ustoichivogo razvitiia predpriiatii [Management of sustainable development of enterprises], Centr uchebnoi literatury, Kiev, Ukraine, 648 p.

(c) $(1) \Theta$

Цей твір ліцензовано на умовах Ліцензії Creative Commons «/3 Зазначенням Aвторства - Некомериійна 4.0 Міжнародна» (CC BY-NC 4.0). This is an open access journal and all published articles are licensed under a Creative Commons "Attribution-NonCommercial 4.0 International" (CC BY-NC 4.0). 